\title{
O ZASADZIE BEZPOŚREDNIOŚCI W PERSPEKTYWIE ZMIAN KODEKSU POSTEPPOWANIA KARNEGO
}

W sierpniu 2012 r. przypada dziesiąta już rocznica śmierci znakomitego procesualisty karnego - Profesora dr hab. Tadeusza Nowaka ${ }^{1}$. W dorobku naukowym zmarłego Profesora istotne miejsce zajmowały rozważania o zasadzie bezpośredniości w polskim procesie karnym. W doktrynie, a także w judykaturze problematyka zasad procesowych i ich wpływu na model polskiego procesu karnego zajmuje od lat przedwojennych znaczące miejsce ${ }^{2}$, jednak najgoręcej dyskutowano o systemie zasad procesowych oraz o ich znaczeniu dla budowy i funkcjonowania polskiego modelu procesu karnego $\mathrm{w}$ latach sześćdziesiątych i siedemdziesiątych ubiegłego wieku ${ }^{3}$. Profesor T. Nowak wpisał się także w tę dyskusję jako autor ważnej i często cytowanej w piśmiennictwie monografii, zatytułowanej Zasada bezpośredniości $w$ polskim procesie karnym ${ }^{4}$ (była to jego rozprawa habilitacyjna). Praca ta powstała w 1971 r., a zatem krótko po wejściu w życie pierwszego powojennego Kodeksu postępowania karnego (z 1969 r.), a jeszcze na wiele lat przed uchwaleniem obecnie obowiązującej ustawy karnoprocesowej z 6 czerwca 1997 r. $^{5}$

Monografia T. Nowaka zachowała, mimo upływu czasu i zmiany stanu prawnego, znaczącą aktualność w zakresie rozważań teoretycznych poświęconych tytułowej zasadzie procesowej. Zgłoszone przez autora propozycje nie były kwestionowane w doktrynie. Wręcz przeciwnie. Poglądy T. Nowaka dotyczące postulatów charakteryzujących zasadę bezpośredniości stanowią pewien kanon rozumienia istoty tej dyrektywy i jej oddziaływania na przebieg i wyniki postępowania dowodowego w procesie karnym. Być może właśnie z tych względów Profesor T. Nowak nie powracał już później, pod rządami nowego Kodeksu postępowania karnego, do zagadnień związanych z zasadą

${ }^{1}$ Prof. dr hab. Tadeusz Nowak (1929-2002) był w latach 1974-1999 kierownikiem Katedry Postępowania Karnego na Wydziale Prawa i Administracji Uniwersytetu im. A. Mickiewicza w Poznaniu.

${ }^{2}$ Por. E. Krzymuski, Wyktad procesu karnego, Kraków 1922, s. 13; L. Schaff, Zasada bezpośredniości w procesie karnym Polski Ludowej, „Wojskowy Przegląd Prawniczy” 1953, nr 4, s. 336.

${ }^{3}$ Por. M. Cieślak, Zasady procesu karnego i ich system, w: idem, Dzieła wybrane, t. IV: Prawo karne procesowe. Artykuty, studia inne prace, pod red. S. Waltosia, Kraków 2011; M. Cieślak, Polska procedura karna. Podstawowe zatożenia teoretyczne, w: idem, Dzieła wybrane, t. II, pod red. S. Waltosia, Kraków 2011; J. Haber, Podstawowe zasady procesu karnego w świetle projektu kodeksu postepowania karnego, „Państwo i Prawo” 1969, z. 2, s. 296-297.

${ }^{4}$ T. Nowak, Zasada bezpośredniości w polskim procesie karnym, Poznań 1971.

${ }^{5}$ Ustawa z 6 czerwca 1997 r. - Kodeks postępowania karnego, Dz. U. Nr 89, poz. 555 z późn. zm. 
bezpośredniości i nie analizował jej znaczenia dla nowego (po 1998 r.) modelu polskiego procesu karnego.

W zmienionym pod rządami nowego kodeksu prawie karnym procesowym znaczenie zasady bezpośredniości jednak nie zmalało. Miała ona znaczący wpływ na normatywne ujęcie postępowania dowodowego prowadzonego $\mathrm{w}$ toku rozprawy przez sąd, a także na określenie ustawowych granic, w jakich możliwe są odstępstwa od bezpośredniości. Sposób ukształtowania postępowania dowodowego przed sądem, uwzględniający dyrektywy płynące $\mathrm{z}$ zasady bezpośredniości ujmowanej w sposób dość zbliżony zarówno przez T. Nowaka, jak i innych autorów ${ }^{6}$, nie był w początkowym okresie obowiązywania nowego Kodeksu postępowania karnego z $1997 \mathrm{r}$. zasadniczo odmienny od regulacji zawartej w Kodeksie z 1969 r. Przedwczesna śmierć Profesora nie pozwoliła mu jednak poznać wielkiej nowelizacji Kodeksu postępowania karnego z 10 stycznia 2003 r. ${ }^{7}$ Zmiany, jakie ze soba przyniosła ta nowelizacja, wskazują na ewolucję w inkorporacji zasady bezpośredniości do systemu prawa karnego procesowego i odmienne od wcześniejszego ukształtowanie instytucji procesowych z nią związanych.

Tytuł niniejszego artykułu, poświęconego pamięci Profesora Tadeusza Nowaka, ma zatem sygnalizować czytelnikowi pewną dynamikę w sposobie normatywnego ujęcia dyrektywy postępowania, jaka jest zasada bezpośredniości. Rozważania poniższe będą dotyczyć zarówno obecnego stanu prawnego, stanowiącego nieznany Profesorowi efekt prac nowelizacyjnych z 2003 r., jak też perspektywy zmian zarysowanych w Projekcie ustawy o zmianie ustawy Kodeks postępowania karnego, stanowiącym owoc prac Komisji Kodyfikacyjnej Prawa Karnego powołanej przez Ministra Sprawiedliwości w 2009 r.

Zasada bezpośredniości, jako opisująca sposób prowadzenia przez organ procesowy (przede wszystkim sąd) postępowania dowodowego, była i jest zasada nieskodyfikowaną. Jej obowiązywanie w polskim systemie prawa karnego procesowego oraz wpływ na model procesu karnego sa jednak niekwestionowane i istotne. Prezentując tę zasadę w latach siedemdziesiątych ubiegłego wieku, Profesor T. Nowak podkreślał, iż stanowi ona ,ogólne zalecenie dla sądu, innych organów procesowych i stron procesowych, aby w toku rozprawy sądowej sąd korzystał z takiego materiału dowodowego, który jest najbliższy poznawanemu zdarzeniu faktycznemu, a który winien być przeprowadzony wobec całego składu sędziowskiego, gdzie zarówno sąd, jak strony procesowe maja możność zetknięcia się zarówno ze źródłem, jak i środkiem dowodowym"8. Sens tej dyrektywy w jej ujęciu abstrakcyjnym ${ }^{9}$ dotyczy zatem przede wszystkim postępowania dowodowego prowadzonego przez sąd, który powinien zapoznawać się ze wszystkim źródłami i środkami dowodowymi, jakie mają stanowić

${ }^{6}$ Por. M. Cieślak, Polska procedura karna. Podstawowe założenia teoretyczne, Warszawa 1984; A. Murzynowski, Istota i zasady procesu karnego, Warszawa 1994; A. Gaberle, Dowody w sadowym procesie karnym, Kraków 2007; R. Kmiecik, Prawo dowodowe. Zarys wyktadu, Warszawa 2008.

7 Ustawa z 10 stycznia 2003 r. o zmianie ustawy - Kodeks postępowania karnego, ustawy - Przepisy wprowadzające Kodeks postępowania karnego, ustawy o świadku koronnym oraz ustawy o ochronie informacji niejawnych, Dz. U. Nr 17, poz. 155.

${ }^{8}$ T. Nowak, op. cit., s. 45.

${ }^{9}$ M. Cieślak, Zasady procesu..., s. 20 i n. 
podstawę orzeczenia, w całym swym składzie osobowym (składzie orzekającym). Realizację zasady może zapewnić - zdaniem T. Nowaka - łączne przyjęcie trzech postulatów. Pierwszym z nich jest nakaz korzystania przede wszystkim z dowodów pierwotnych przed dowodami pochodnymi, drugim - postulat opierania się przez sąd na materiale dowodowym przeprowadzonym bezpośrednio na rozprawie sądowej, a ostatnim - postulat bezpośredniego zetknięcia się przez sąd orzekający ze źródłem i środkiem dowodowym ${ }^{10}$. Największe znaczenie powinna mieć zatem zasada bezpośredniości w postępowaniu przed sądem pierwszej instancji, choć dostrzegalne jest jej oddziaływania, a także ograniczenia zarówno w stadium przygotowawczym, jak i w postępowaniu sądowym - odwoławczym i kasacyjnym.

Model procesu karnego ukształtowany przepisami k.p.k. z 1997 r. przewiduje realizację nakazów płynących $\mathrm{z}$ abstrakcyjnego ujęcia zasady bezpośredniości przede wszystkim w toku rozprawy głównej, co zauważalne jest choćby $\mathrm{w}$ treści art. 410 k.p.k. Przepis ten nakazuje sądowi przystępującemu do wydania wyroku czynienie ustaleń faktycznych i dokonanie ich oceny prawnej $\mathrm{z}$ uwzględnieniem całokształtu materiału dowodowego ujawnionego $\mathrm{w}$ toku rozprawy głównej. Sąd wyrokujący (i to w całym swoim składzie) ma obowiązek zetknąć się na rozprawie bezpośrednio $\mathrm{z}$ dowodami, zanim rozstrzygnie o odpowiedzialności prawnej oskarżonego za zarzucony mu przez oskarżyciela czyn zabroniony. Zasada bezpośredniości, choć de lege lata dominuje w sposobie ukształtowania modelu rozprawy głównej, a zwłaszcza przewodu sądowego stanowiącego etap przeprowadzania dowodów, to jednak doznaje pewnych ograniczeń. Ujmując tę kwestię tylko skrótowo, należy wskazać na odstępstwo od dyrektywy, iż sąd ma na rozprawie zetknąć się bezpośrednio z osobowymi źródłami dowodowymi, wynikajace $\mathrm{z}$ regulacji zezwalajacej na odczytanie w odpowiednim zakresie złożonych poprzednio przez świadka zeznań w postępowaniu przygotowawczym albo przed sądem w tej lub innej sprawie, jeżeli zajdą określone okoliczności ${ }^{11}$. Wolno również sądowi odczytywać protokoły złożonych uprzednio przez świadka wyjaśnień złożonych w odmiennej roli procesowej oskarżonego lub podejrzanego ${ }^{12}$, jeżeli osoba taka obecnie jest przesłuchiwana jako świadek. Kolejnym odstępstwem od zasady bezpośredniości jest upoważnienie do odczytywania na rozprawie głównej protokołów przesłuchania świadków i oskarżonych sporządzonych w postępowaniu przygotowawczym lub przed sądem albo innym postępowaniu przewidzianym przez ustawę, gdy w ocenie sądu bezpośrednie przeprowadzenie dowodu nie jest niezbędne, a żadna $\mathrm{z}$ obecnych stron się temu nie sprzeciwia (przy czym sprzeciw strony, której zeznania lub wyjaśnienia nie dotycza, nie stanowi przeszkody $\mathrm{w}$ odczytaniu tych dokumentów ${ }^{13}$. Na rozprawie wolno także odczytywać inne protokoły i dokumenty wymienione wyraźnie w przepisach Kodeksu postępowania karnego ${ }^{14}$, a nawet uznać niektóre $\mathrm{z}$ dokumentów (obejmujących dane dotyczące osoby oskarżonego oraz wyniki wywiadu

\footnotetext{
10 T. Nowak, op. cit., s. 48-51.

11 Art. 391 \& 1 k.p.k.

12 Art. 391 § 2 k.p.k.

${ }_{13}$ Art. 392 k.p.k.

${ }^{14}$ Art. 393 § 1 k.p.k.
} 
środowiskowego) za ujawnione bez ich odczytywania ${ }^{15}$. Sa to wyraźne odstępstwa od zasady bezpośredniości, ale nie stanowią one jeszcze podstawy do uznania całkowitego prymatu zasady jej przeciwnej, to znaczy zasady pośredniości. Zupełnie jednak inaczej ujęta jest zasada bezpośredniości przy instytucji merytorycznego pierwszoinstancyjnego wyrokowania poza rozprawa, o czym będzie jeszcze mowa w dalszej części opracowania.

Wspomniana wyżej nowelizacja styczniowa z $2003 \mathrm{r}$. zmieniła ponad 1/3 przepisów wówczas wciąż przecież „,nowego” Kodeksu postępowania karnego ${ }^{16}$. Zmianie uległy również niektóre regulacje stanowiące wcześniej odzwierciedlenie zasady bezpośredniości w polskim prawie karnym procesowym. Należy pamiętać, że głównym założeniem tej nowelizacji było usprawnienie i przyspieszenie procesu karnego ${ }^{17}$. Wprowadzono wówczas do polskiego systemu prawa karnego procesowego możliwość wydawania w sądzie pierwszej instancji wyroku merytorycznego poza rozprawą główna - na posiedzeniu wyrokowym ${ }^{18}$. Analizując zmiany dokonane nowelizacja styczniową w kontekście zasady bezpośredniości i jej dyrektyw, wydaje się uprawnione sformułowanie tezy, iż zmiany wprowadzone do polskiego prawa karnego procesowego w $2003 \mathrm{r}$. w sposób znaczący ograniczyły, a niekiedy wprost wyłączyły ${ }^{19}$ (zwłaszcza $\mathrm{w}$ trybie orzekania merytorycznego poza rozprawą) nakazy płynące $\mathrm{z}$ zasady bezpośredniości w jej ujęciu abstrakcyjnym.

Pewnym modyfikacjom w kierunku pośredniości postępowania dowodowego poddano wówczas także przepisy dotyczące postępowania dowodowego na rozprawie głównej, a wśród nich art. 389 § 1, 391 § 1, 392, 393 § 1, 393 § 2, 393a, $394 \S 2$ k.p.k.

Konsekwencja przyjętych w $2003 \mathrm{r}$. rozwiązań normatywnych było - jak wyżej wspomniano - znaczące ograniczenie zasady bezpośredniości, polegające głównie na pozbawieniu sądu możliwości zetknięcia się bezpośrednio z dowodami przed wydaniem wyroku. Dowodzenie na każdym etapie postępowania karnego, a zwłaszcza w postępowaniu przed sądem polega na wykazywaniu za pomoca dowodów i odpowiedniej argumentacji istnienia albo nieistnienia określonych faktów i powiązań między nimi. W procesie karnym dowodem może być wszystko, co dopuszczalne jest przez prawo karne procesowe $\mathrm{w}$ celu wydania rozstrzygnięcia. Istotne jest jednak to, by wszelkie dowody przeprowadzone zostały $\mathrm{w}$ procesie $\mathrm{w}$ sposób przewidziany przez ustawę. Tylko

15 Art. 394 k.p.k.

${ }^{16}$ Ustawa z 10 stycznia 2003 r. o zmianie ustawy - Kodeks postępowania karnego, ustawy - przepisy wprowadzające Kodeks postępowania karnego, ustawy o świadku koronnym oraz ustawy o ochronie informacji niejawnych, Dz. U. Nr 17, poz. 155; weszła w życie 1 lipca 2003 r.

17 Por. S. Waltoś, Gtówne nurty nowelizacji procedury karnej, „Państwo i Prawo” 2003, z. 4; idem, Pragmatyczne watki wielkiej nowelizacji procesu karnego, w: A. Marek (red.), Wspótczesne problemy procesu karnego i jego efektywności. Księga Pamiatkowa Profesora Andrzeja Bulsiewicza, Toruń 2004.

${ }^{18}$ Zagadnienie to omawiam szerzej w monografii - por. H. Paluszkiewicz, Pierwszoinstancyjne wyrokowanie merytoryczne poza rozprawa gtówna w polskim procesie karnym, Warszawa 2008.

${ }^{19}$ Szerzej H. Paluszkiewicz, Zasada bezpośredniości a wyrokowanie poza rozprawa $w$ świetle kodeksu postepowania karnego, w: B. Janiszewski (red.), Nauka wobec wspótczesnych zagadnień prawa karnego $w$ Polsce. Księa pamiatkowa ofiarowana Profesorowi Aleksandrowi Tobisowi, Poznań 2004, s. 175-185; eadem, $Z$ problematyki dowodzenia na posiedzeniu wyrokowym, w: J. Skorupka (red.), Rzetelny proces karny. Ksiega Jubileuszowa profesor Zofii Swidy, Warszawa 2009, s. 403-415. 
takie dowody są w swej istocie ,dowodami”, a zatem mogą stać się podstawa twierdzeń o istnieniu lub nieistnieniu określonych faktów o znaczeniu procesowym. Nowelizacja styczniowa stworzyła taki stan prawny, w którym prowadzenie przez sąd postępowania dowodowego $\mathrm{w}$ sprawie zastąpiono koniecznościa polegania na materiale dowodowym zgromadzonym przez organy prowadzące śledztwo lub dochodzenie w stadium postępowania przygotowawczego. Pojawiły się bowiem wówczas na nowo ukształtowane przepisy normujące skazanie na wniosek prokuratora (art. $335 \mathrm{w} \mathrm{zw.} \mathrm{z} \mathrm{art.} 339$ § 3 k.p.k.), orzekanie o warunkowym umorzeniu postępowania karnego (art. $332 \mathrm{w} z w$. z art. 341 i 342 k.p.k.), skazanie w wyniku uwzględnienia wniosku oskarżonego o dobrowolne poddanie się odpowiedzialności (art. 474a k.p.k.), a także postępowanie nakazowe (art. 500-507 k.p.k.). Wspólnym rysem tych nowych regulacji stało się to, że wyrok w kwestii odpowiedzialności karnej oskarżonego zapada bez jawnej rozprawy $\mathrm{i}$ bez przeprowadzania przez sąd pełnego postępowania dowodowego ${ }^{20}$.

Wskazując na zmiany dokonane nowelizacją styczniową, należy także wspomnieć o ograniczeniu zasady bezpośredniości dostrzegalnym w nowym ukształtowaniu art. 185 k.p.k. i dodanym wówczas nowym art. 185a k.p.k. ${ }^{21}$ Pomijając w tym miejscu zasługujący na akceptację sens i cel zmiany wskazanych przepisów (mających ochronić małoletnich pokrzywdzonych i świadków przed wtórna wiktymizacja poprzez umożliwienie przesłuchania ich w szczególny sposób przez sąd jeszcze w postępowaniu przygotowawczym), zwrócić należy uwagę na to, jak dowód z tego źródła będzie wykorzystany na dalszym etapie procesu. Otóż skoro regułą ma być przesłuchanie małoletniego w charakterze świadka tylko jeden raz w przygotowawczym stadium procesu, to po to, by na rozprawie uniknąć ponawiania tej czynności dowodowej. Dowód z zeznań świadka ma być wówczas przeprowadzany z ograniczeniem zasady bezpośredniości, gdyż na rozprawie odczytuje się tylko protokół jego zeznań sporządzony $\mathrm{w}$ postępowaniu przygotowawczym, a jeżeli zostanie również dokonane utrwalenie czynności przesłuchania w formie zapisu obrazu i dźwięku, należy go także odtworzyć (art. 185a § 3 k.p.k.).

Omawiając zmiany w Kodeksie postępowania karnego dokonane po 1997 r., warto wskazać także na nowelizację dokonaną ustawą z 31 sierpnia $2011 \mathrm{r}$. o zmianie ustawy o bezpieczeństwie imprez masowych oraz niektórych innych ustaw $^{22}$, w wyniku której zmodyfikowano między innymi dokonywanie sądowych czynności procesowych z udziałem sprawcy (ujętego w warunkach określonych w art. 517b $\S 1$ k.p.k.) poprzez użycie urządzeń technicznych, umożliwiających dokonywanie tych czynności na odległość z jednoczesnym bezpośrednim przekazem obrazu i dźwięku. Szerszy zakres zmian i zupełnie nowe przepisy wprowadzone tą ustawą dotyczą zwłaszcza trybu przyspieszonego, jednak i w innych rozdziałach Kodeksu postępowania karnego można odnaleźć nowe regulacje na przykład art. $177 \S 1$ a k.p.k. W nowym brzmieniu zezwala na dokonanie czynności przesłuchania świadka przy pomocy urządzeń

\footnotetext{
${ }^{20}$ A nawet bez udziału stron - por. art. 500 k.p.k.

${ }^{21}$ Art. $185 \mathrm{a} \S 1$ i $\S 3$ oraz art. 185b k.p.k. były zmieniane również w 2005 r. - ustawa z 3 czerwca 2005 r., Dz. U. Nr 141, poz. 1181; weszła w życie 29 sierpnia 2005 r.

${ }^{22}$ Dz. U. Nr 217, poz. 1280.
} 
technicznych umożliwiających dokonanie tej czynności na odległość z jednoczesnym bezpośrednim przekazem obrazu i dźwięku, przy czym w związku $\mathrm{z}$ dokonywaniem tej czynności w miejscu pobytu świadka, a nie w siedzibie sądu ustawa zakłada udział w tej czynności w miejscu jej dokonywania referendarza sądowego, asystenta sędziego lub urzędnika zatrudnionego w sądzie, w którego okręgu świadek przebywa. Wprowadzając szczególne reguły przeprowadzania dowodów ze źródeł osobowych (świadkowie, oskarżony), ustawodawca uznał jednak $^{23}$, że nowe rozwiązania nie stanowią naruszenia naczelnych zasad procesowych. Wyraźnie jednak zauważalne jest nadanie zupełnie innego znaczenia dyrektywie „,bezpośredniego” zetknięcia się sądu z dowodem.

Przedstawienie przygotowanego przez Komisję Kodyfikacyjną Projektu zmian w kodeksie postępowania karnego stawia pytanie o to, jak projektodawcy postrzegają realizację dyrektyw płynących z zasady bezpośredniości. Lektura Projektu, a także jego Uzasadnienia pozwala na stwierdzenie, że wpływ abstrakcyjnie ujmowanej zasady bezpośredniości na model polskiego procesu karnego jest wyraźnie dostrzegalny także de lege ferenda. Zauważalny jest jednak odmienny sposób skonkretyzowania tej zasady, odnajdywany w obecnych i w przyszłych (projektowanych) regulacjach prawnych. Zasadnicze zmiany, jakie proponuje Komisja Kodyfikacyjna w zakresie modelu dowodzenia, dotyczą przede wszystkim sposobu prowadzenia postępowania dowodowego, i to zarówno na rozprawie, jak i poza nią. Na tym tle rysuje się również bardzo wyraźne zupełnie odmienne od dotychczasowego ujęcie zasady bezpośredniości, a ściślej rzecz ujmując, nowe od niej odstępstwa.

Próba przebudowy modelu polskiego procesu karnego w kierunku zwiększenia jego kontradyktoryjności pociagga za sobą propozycję Komisji Kodyfikacyjnej w zakresie wprowadzania dowodów, jak też reguł ich przeprowadzania na rozprawie i poza nią. Jak wynika z Uzasadnienia projektu ${ }^{24}$, zasadniczą zmiana proponowaną przez Komisję w zakresie postępowania dowodowego jest nadanie nowego brzmienia obecnemu art. 167 k.p.k. Przepis ten określa de lege lata inicjatywę $\mathrm{w}$ zakresie wprowadzania dowodów do procesu, przewidując, że należy ona także do sądu, który może przeprowadzić dowód z urzędu. Proponuje się nadanie art. 167 k.p.k. zupełnie nowej struktury, uwzględniającej inicjatywę $\mathrm{w}$ zakresie przeprowadzania dowodów w procesie, i to odmiennie ukształtowana w postępowaniu przygotowawczym i postępowaniu sądowym, a także uwzględniająca to, czy postępowanie zostało wszczęte $\mathrm{z}$ inicjatywy strony, czy też $\mathrm{z}$ urzędu. Sposób przeprowadzania dowodu będzie zatem ukształtowany różnie, w zależności od wyżej wskazanych czynników. Projekt zakłada, że we wszystkich postępowaniach przed sądem wszczynanych z inicjatywy strony procesowej $^{25}$ inicjatywa dowodowa ma należeć do stron, a sąd będzie mógł

\footnotetext{
${ }^{23}$ Uzasadnienie projektu Ministerstwa Sprawiedliwości z 9 lutego 2011 r., s. 37-39; Uzasadnienie rządowego projektu ustawy o zmianie ustawy o bezpieczeństwie imprez masowych oraz o zmianie niektórych innych ustaw, a także o zapewnieniu bezpieczeństwa w związku z organizacją Turnieju Finałowego UEFA EURO 2012 (druk nr 4281), s. 26-27.

${ }^{24}$ Uzasadnienie projektu ustawy o zmianie ustawy Kodeks postępowania karnego i niektórych innych ustaw, grudzień 2011 (dalej: Uzasadnienie projektu).

${ }^{25}$ Co będzie dotyczyć zarówno postępowania po wniesieniu publicznego i prywatnego aktu oskarżenia, jak i postępowań inicjowanych wniesieniem środków odwoławczych oraz wszelkich wniosków.
} 
wprowadzić do procesu dowód jedynie w wyjątkowych, szczególnie uzasadnionych wypadkach (proj. art. 167 § 1 k.p.k.). Ten nowy sposób procedowania w opinii Komisji ${ }^{26}$ - zwalnia sąd od ,,poszukiwania” dowodów winy oskarżonego w sytuacji, gdy oskarżyciel tego nie czyni. Dowody mają być zatem przeprowadzane przed sądem przez tę stronę, na wniosek której został dany środek dowodowy dopuszczony, co oznacza, że ta właśnie strona w pierwszej kolejności zadaje pytania osobom przesłuchiwanym ${ }^{27}$, prezentuje dowody rzeczowe i tak dalej. Sąd będzie mógł wyręczyć stronę jedynie wyjątkowo, gdy uzna, że przejęcie inicjatywy jest szczególnie uzasadnione i przyczyni się do sprawniejszego osiągnięcia celów procesu. Takie ujęcie niesie za sobą określone konsekwencje w normatywnym ukształtowaniu przeprowadzania dowodów $\mathrm{w}$ toku rozprawy głównej, a tym samym wyznacza poziom inkorporacji dyrektyw płynących z abstrakcyjnie ujmowanej zasady bezpośredniości do modelu polskiego procesu karnego de lege ferenda.

Zmiany, jakie przynosi Projekt, obejmuja zwłaszcza postępowanie dowodowe $\mathrm{w}$ toku przewodu sądowego na rozprawie pierwszoinstancyjnej. W niewielkim stopniu modyfikacji ulec maja zasady budowania podstawy faktycznej przy orzekaniu przez są poza rozprawa (na posiedzeniu). W tym ostatnim przypadku warto jednak zwrócić uwagę, iż nowe brzmienie ma otrzymać art. 97 k.p.k., który stanowić będzie nadal zasadnicze ramy prawne ustalania (sprawdzania) okoliczności faktycznych przed wydaniem orzeczenia na posiedzeniu. Dodanie reguły, że czynności niewymagające przeprowadzenia dowodu moga być w toku posiedzenia wykonywane przez referendarza sądowego, zdaje się potwierdzać, iż sąd może prowadzić postępowanie dowodowe na posiedzeniu, zanim wyda orzeczenie (postanowienie lub wyrok). Kwestia ta była pod rządami Kodeksu postępowania karnego z 1997 r. (zwłaszcza po 2003 r. i wejściu w życie nowelizacji styczniowej) dyskutowana $\mathrm{w}$ doktrynie ${ }^{28}$. Utrzymane zostana dotychczasowe reguły budowania podstawy faktycznej wyroków wydawanych na posiedzeniu. Zmiany proponowane przez Komisję, polegajace na dodaniu nowych art. 338a i art. 343a k.p.k. oraz nowelizacja w obrębie art. 343 k.p.k., nie zmieniają dotychczasowych odstępstw od zasady bezpośredniości, pozostanie bowiem reguła, że sąd nie przeprowadza postępowania dowodowego przed wydaniem wyroku skazującego na posiedzeniu wyrokowym. Utrwalona zostanie zatem praktyka (znajdująca de lege lata podstawę w ustawie) wydawania wyroku merytorycznego na posiedzeniu $\mathrm{w}$ oparciu o materiał dowodowy zgromadzony w postępowaniu przygotowawczym, zwłaszcza jeśli nie będzie on kwestionowany ani przez wnoszącego skargę oskarżyciela, ani przez pokrzywdzonego (który de facto akceptuje

\footnotetext{
${ }^{26}$ Uzasadnienie projektu, s. 10.

${ }^{27} \mathrm{Z}$ nowym ukształtowaniem reguł dopuszczania i przeprowadzania dowodów przed sądem wiąże się proponowana zmiana art. 370 k.p.k., określającego zasady przeprowadzania przesłuchania. Proponuje się mianowicie, by w wypadku przeprowadzania tego dowodu przez stronę, zawsze zadawała ona pytania osobie przesłuchiwanej w pierwszej kolejności, a członkowie sądu mieli takie uprawnienie tylko wyjątkowo i czynili to zawsze w ostatniej kolejności (proj. art. 370 § 1 i 2 k.p.k.).

${ }^{28}$ Por. H. Paluszkiewicz, Pierwszoinstancyjne wyrokowanie..., s. 240-254 i cytowana tam literatura; eadem, $Z$ problematyki...; P. Hofmański, S. Zabłocki, Elementy metodyki pracy sędziego $w$ sprawach karnych, Kraków 2006, s. 136 i n.
} 
ustalenia faktyczne, nie sprzeciwiając się propozycji wydawanego na posiedzeniu wyroku), ani też przez samego oskarżonego, który przecież może inicjować ten sposób orzekania o jego odpowiedzialności prawnej za popełniony czyn zabroniony.

Znaczące zmiany mają natomiast dotyczyć przeprowadzania dowodów $\mathrm{w}$ toku przewodu sądowego na rozprawie głównej. Zmiany zaproponowane w art. 389 k.p.k. sa przede wszystkim konsekwencja modyfikacji reguł w zakresie udziału oskarżonego w rozprawie głównej (art. 374-377 k.p.k.). W przeciwieństwie do obecnych uregulowań zakładających obowiązkową obecność oskarżonego na rozprawie pierwszoinstancyjnej, a tym samym jego obecność $\mathrm{w}$ toku przewodu sądowego służącego przeprowadzaniu przez sąd dowodów, nowe przepisy przewidują jedynie prawo oskarżonego do udziału w rozprawie, wskazując tylko na wyjątki, kiedy obecność ta ma być obowiązkowa (nowy art. 374 § 1 i $\$ 1$ a k.p.k.). Jak trafnie uznaja projektodawcy ${ }^{29}$, wyeliminowanie obligatoryjnego udziału oskarżonego w rozprawie jako zasady pociąga za sobą także między innymi konieczność uwzględnienia tej okoliczności przy określeniu na nowo reguł dotyczących odczytywania jego uprzednich wyjaśnień. Stąd propozycje odpowiednich zmian w art. 389, 391, 393 i 394 k.p.k.

W obrębie art. $389 \S 1$ k.p.k. proponuje się rozszerzenie zakresu podstaw uprawniających do odczytania na rozprawie $\mathrm{w}$ odpowiednim zakresie protokołów uprzednich wyjaśnień oskarżonego o sytuację, w której oskarżony nie stawił się na rozprawę. Pozostałe przesłanki oraz zakres protokołów podlegających odczytaniu maja pozostać bez zmian. Modyfikacja wprowadzona w $\S 2$ art. 389 k.p.k. polega natomiast jedynie na wskazaniu, że uprawnienie wypowiedzenia się co do odczytanych $\mathrm{w}$ trybie $\S 1$ własnych wyjaśnień przysługuje wyłącznie oskarżonemu biorącemu udział $\mathrm{w}$ rozprawie. Nieobecność oskarżonego na rozprawie otwiera drogę do odczytania protokołów jego uprzednich wyjaśnień, ale jednocześnie zwalnia sąd $\mathrm{z}$ obowiązku zapewnienia oskarżonemu odrębnej możliwości wypowiedzenia się co do tak ujawnionego materiału dowodowego, przy tym jednak nie wyklucza możliwości złożenia wyjaśnień przez oskarżonego na późniejszym etapie postępowania dowodowego na rozprawie głównej. W przepisie tym pojawić ma się także nowa jednostka redakcyjna oznaczona jako § 3 , przewidujący możliwość odczytania na rozprawie wyjaśnień współoskarżonego, który zmarł. Jak wskazuja projektodawcy w Uzasadnieniu projektu ${ }^{30}$, wprowadzenie tego rozwiązania stanowi realizację zgłaszanych od dawna postulatów, a także akceptację stanowiska Sądu Najwyższego ${ }^{31}$, który dopatruje się upoważnienia do takiego odczytania na zasadzie a maiori ad minus w art. $389 \S 1$ k.p.k. Proponowana zmiana ma być też potwierdzeniem, iż wraz ze śmiercią współoskarżonego dowód z jego wyjaśnień nie przestaje istnieć ani nie ulega przekształceniu w inny środek dowodowy, a jego wykorzystanie stanowi wyraz realizacji w procesie karnym zasady prawdy.

\footnotetext{
${ }^{29}$ Uzasadnienie projektu, s. 131.

${ }^{30}$ Uzasadnienie projektu, s. 132.

${ }^{31}$ Wyrok SN z 6 grudnia 2006 r., III KK 181/06, OSNKW 2007, nr 2, poz. 16.
} 
Zmiany proponowane przez Komisję obejmuja również art. 391 k.p.k. Propozycja nowej redakcji tego przepisu polega na rozdzielenia przesłanek wprowadzających odstępstwo od bezpośredniości w kontakcie sądu na rozprawie z dowodami z zeznań świadka na odstępstwa wprowadzane pomimo obecności świadka na rozprawie oraz odstępstwa ze względu na jego nieobecność. Sam katalog przesłanek nie ulega zmianie - modyfikacji podlegaja jednak zasady wprowadzania tych dowodów do procesu. W nowej jednostce redakcyjnej pozostanie jako $\S 1$ dotychczasowa treść art. 391 k.p.k., która zgodnie z Projektem odnosić się ma do pierwszej grupy sytuacji: ma umożliwić odczytywanie protokołów pomimo udziału świadka w rozprawie. Będzie to możliwe w sytuacji bezpodstawnej odmowy zeznań, złożenia zeznań odmiennych od składanych uprzednio albo oświadczenia świadka, że pewnych szczegółów nie pamięta. W tym ostatnim przypadku Projekt przewiduje możliwość odczytywania protokołów, jeśli świadek nie pamięta pewnych „,szczegółów”, a nie - jak to dotąd ujmowano - „okoliczności”. W ocenie projektodawców, taka redakcja omawianego przepisu ma podkreślić subsydiarny charakter czynności odczytania protokołu uprzednich zeznań świadkaw stosunku do ich bezpośredniego złożenia na rozprawie. Poza wydzieleniem przesłanek odczytywania uprzednio złożonych zeznań świadka nowy art. 391 k.p.k. zasadniczo zmienia zasady wprowadzania na rozprawę jako materiału dowodowego $\mathrm{w}$ sprawie protokołów wcześniejszych przesłuchań. Zgodnie z Projektem możliwe ma to być przede wszystkim na wniosek strony, $\mathrm{z}$ urzędu zaś wyłącznie $\mathrm{w}$ wyjątkowych, szczególnie uzasadnionych przypadkach (proj. art. $167 \S 1$ zd. 3 k.p.k.) albo w postępowaniu wszczętym z urzędu (proj. art. $167 \S 2$ k.p.k.). Celem tego rozwiązania jest dążenie do zapewnienia stronom możliwości większej aktywności w zakresie prowadzonego postępowania dowodowego, przy jednoczesnym ograniczeniu aktywności sądu działającego z urzędu, co w sposób wyraźny pozostaje w związku z propozycją nowego ukształtowania art. 167 k.p.k. Jednocześnie wyłączona będzie możliwość uznawania za ujawnione protokołów takich zeznań bez ich odczytywania (wyłączenie stosowania art. $394 \S 2$ k.p.k.). Ta propozycja uzasadniana jest faktem, że dotyczy sytuacji, w których istnieje rozbieżność między zeznaniami, rodząca potrzebę konfrontacji (świadek składa zeznania odmienne), konieczna jest ich weryfikacja (świadek pewnych szczegółów nie pamięta) albo jest to jedyny sposób uzyskania zeznań (świadek bezpodstawnie odmawia złożenia zeznań). W każdej z tych sytuacji odczytanie poprzednich zeznań na rozprawie jest niezbędne.

Projektowany nowy $\S 1 \mathrm{a}$ art. 391 k.p.k. odnosi się natomiast do sytuacji, w których powodem odczytania protokołów zeznań świadka jest jego nieobecność na rozprawie, wynikająca $\mathrm{z}$ takich przyczyn, jak pobyt za granica, niemożność jego wezwania na rozprawę, niestawiennictwo $\mathrm{z}$ powodu „niedających się usunąć przeszkód”, śmierci świadka oraz zaniechania wezwania go w sytuacji, o której mowa w art. $333 \S 2$ k.p.k., to jest potrzeba stwierdzenia w oparciu o jego zeznania okoliczności niespornych, niemających waloru doniosłości dla sprawy. Projekt przewiduje w tym zakresie taki sam tryb wprowadzania dowodów, jaki proponuje się w $§ 1$, z tym że art. $394 \S 2$ k.p.k. będzie mógł być w takim wypadku odpowiednio stosowany. Możliwe będzie 
zatem uznanie protokołów zeznań świadka za ujawnione bez ich odczytywania, o ile o odczytanie nie wniesie strona, która nie miała możliwości zapoznania się $\mathrm{z}$ ich treścią.

Kolejną zmianą jest nowa redakcja art. $393 \S 3$ k.p.k. Przepis ten de lege lata dotyczy reguł wykorzystania dowodów prywatnych na rozprawie i zgodnie z nim nie wolno odczytywać dokumentów prywatnych powstałych poza postępowaniem karnym i nie dla jego celów. W Projekcie proponuje się rezygnację z tego ostatniego ograniczenia, co stanowić ma jeden z elementów zapewniających obronie możliwość realnego przygotowania się do postępowania przed sądem. Nie jest to bez znaczenia wobec założenia o potrzebie rozszerzenia kontradyktoryjności tego etapu procesu, a w ocenie projektodawców jednocześnie eliminuje nawet kolejne ograniczenie formalne w dążeniu do ustalenia prawdy i stanowi swego rodzaju ,wyrównanie szans” stron procesowych. Dopuszczalne ma być zatem na rozprawie odczytywanie wszelkich dokumentów prywatnych powstałych poza postępowaniem karnym, w tym oświadczeń, publikacji, listów czy notatek ( $\mathrm{z}$ uwzględnieniem jednak zakazu substytuowania wyjaśnień i zeznań - proj. art. 174 k.p.k. ${ }^{32}$ ).

Na uwagę zasługuje propozycja umożliwienia stronom w toku postępowania przygotowawczego złożenia wniosku o przeprowadzenie dowodu przez organ prowadzący to postępowanie, jeśli wnioskodawca ma podstawy przypuszczać, że określonego dowodu z osobowego źródła dowodowego nie będzie można przeprowadzić w dalszym toku procesu na rozprawie. W takim wypadku podczas przewodu sądowego strona będzie mogła wykorzystać uzyskany w postępowaniu przygotowawczym dowód $\mathrm{w}$ ten sposób, iż będzie uprawniona do wnioskowania o załączenie go do materiału dowodowego (wprowadzenie do procesu) bez jego przeprowadzenia - w granicach wyznaczonych treścią art. 389 i 391 k.p.k. Zmiana w sposobie ukształtowania sposobu wprowadzania dowodów do procesu i położenie akcentu na inicjatywę dowodowa stron procesowych $\mathrm{z}$ jednoczesnym ograniczeniem prowadzenia dowodów przez sąd $\mathrm{z}$ urzędu otwiera droge do wzbogacania materiału dowodowego na rozprawie o inne dowody. Strona będzie miała możliwość złożenia wniosku o dopuszczenie dowodu z opinii biegłego (który na przykład sporządził dla obrony opinię) i przesłuchania go przed sądem, jeśli sąd dowód ten dopuści. Opinia tak zwanego prywatnego „biegłego” czy też nagranie dokumentujące oględziny rzeczy lub miejsca będą mogły być przedłożone sądowi. Priorytetem, jak zapewniaja projektodawcy, ma być jednak nadal bezpośrednie przeprowadzenie czy zweryfikowanie dowodu na rozprawie. Co do dowodów rzeczowych także ma obowiazywać reguła, że strona powinna je (stosownie do art. 395 k.p.k.) zaprezentować sądowi na rozprawie (i pozostałym stronom, a w razie potrzeby świadkom i biegłym), jeśli jest to fizycznie możliwe.

W Projekcie przewidziano również zmianę w art. 394 § 2 zd. drugie k.p.k., prowadzącą do rozszerzenia możliwości ujawnienia na rozprawie dowodów bez ich odczytania. Pod rządami obecnego Kodeksu postępowania karnego dowody te muszą być odczytane, jeżeli którakolwiek ze stron o to wnosi. Propozycja

${ }^{32}$ Proponuje się wręcz rozszerzenie zakresu tego zakazu poprzez wskazanie, że dotyczy on nie tylko jak dotąd - treści pism, zapisków lub notatek urzędowych, ale także innych dokumentów. 
Komisji zmierza do tego, aby takie uprawnienie strona zachowała jedynie wówczas, gdy z istotnym dowodem nie miała sposobności zapoznać się wcześniej i łączy się z nadaniem stronom (zwłaszcza pokrzywdzonemu w proj. art. 321 $\S 4$ a k.p.k.) uprawnienia do zapoznawania się $\mathrm{z}$ materiałem dowodowym $\mathrm{w}$ tym stadium procesu zgromadzonym przed zamknięciem tego postępowania, jak i na dalszym etapie procesu - w trybie nowego art. $156 \S 1$ a k.p.k. ${ }^{33}$

Zmiany, jakie proponuje Komisja Kodyfikacyjna, obejmuja także wspomniane wyżej art. 185a i $185 \mathrm{~b}$ k.p.k. Nowe regulacje skorelowano z nadaniem nowego brzmienia art. $147 \S 2$ a k.p.k., który wprowadza obligatoryjność rejestrowania przebiegu przesłuchania świadka na podstawie art. 185a i 185b k.p.k. za pomocą urządzenia rejestrującego obraz i dźwięk. W Uzasadnieniu projektu zwraca się uwagę, że obecnie obowiązująca regulacja pozwala na odstąpienie od rejestrowania przebiegu tej czynności, jeżeli względy techniczne stoja temu na przeszkodzie. Powołując się na przeprowadzone badania, projektodawcy wskazują, że około $60 \%$ przesłuchań przeprowadzanych na podstawie art. 185a i 185b k.p.k. nie jest obecnie utrwalanych za pomoca urządzeń rejestrujacych. Pomijajac oczywiste w tym wypadku stwierdzenie, że brak zapisu obrazu i dźwięku przesłuchania małoletniego może w praktyce podważać jednorazowy charakter tej czynności i wywoływać wnioski oskarżonych o ponowne przesłuchanie świadka, należy w kontekście rozważań o bezpośredniości zauważyć, iż rejestracja przesłuchania i możliwość odtworzenia jego przebiegu na rozprawie lepiej zabezpiecza też realizację zasady bezpośredniości, umożliwiając sądowi zetknięcie się ze źródłem dowodowym i ocenę wiarygodności świadka oraz jego zeznań ${ }^{34}$.

Zasada bezpośredniości jako jedna z dyrektyw wpływających na model polskiego procesu karnego, choć na przestrzeni lat nie zmieniła swej treści, to jednak jako zasada konkretna dająca się odczytać z treści przepisów obowiązujących w danym momencie ustaw karnoprocesowych w sposób zupełnie różny - w różnych okresach - modelowała kształt postępowania dowodowego w stadium jurysdykcyjnym. Zgłaszany przez T. Nowaka postulat, by zasadę tę skodyfikować, z pewnością stracił dziś na aktualności. Jednak nadal pozostaje do rozważenia, czy obecnie obowiązujące, a zwłaszcza projektowane, rozwiązania polegające na zwiększaniu odstępstw od zasady bezpośredniości (rozumianej jako eliminowanie ogniw pośrednich pomiędzy sądem rozpoznającym sprawę a źródłem dowodowym) nie prowadzą do odmiennego niż dotąd rozumienia tej idei. Jeśli de lege ferenda zwiększy się kontradyktoryjność procesu karnego, czego wyrazem mają być choćby reguły i kształt postępowania dowodowego na rozprawie pierwszoinstancyjnej, to warto rozważyć, czy postulat, by sąd stykał się z dowodami bezpośrednio, będzie spełniony, jeśli to ,zetknięcie” będzie polegać także na odtwarzaniu na rozprawie zapisu obrazu i dźwięku utrwalonego w postępowaniu przygotowawczym w toku dokumentacji

\footnotetext{
${ }^{33}$ Udostępnienie nastąpić ma w takim zakresie, w jakim nie przekazano dowodów wraz $\mathrm{z}$ aktem oskarżenia sądowi - proj. $156 \S 1$ a k.p.k.

${ }^{34} \mathrm{~W}$ Uzasadnieniu projektu Komisja podaje, iż w rezultacie projektowanych zmian normatywnych małoletnim świadkom zapewnione zostaną różne poziomy ochrony, uzależnione od ich wieku oraz tego, czy posiadają w postępowaniu karnym status pokrzywdzonego - por. s. 66 i n.
} 
czynności dowodowych dokonywanych przez strony ${ }^{35}$. Być może należy przyjąć, iż rozwój nowych form środków przekazu i stopień przygotowania sądów do korzystania z nieznanych wcześniej rozwiązań technicznych powodują, że bezpośredniość powinna być rozumiana dziś, a zapewne jeszcze bardziej w przyszłości, w odmienny sposób niż w latach siedemdziesiątych ubiegłego wieku. Nie można także wykluczyć, iż zrodzi to na przyszłość potrzebę przedefiniowania dyrektyw płynących z zasady bezpośredniości w jej ujęciu abstrakcyjnym, w kierunku odmiennym od przyjmowanego przez Profesora T. Nowaka w jego dziele.

dr hab. Hanna Paluszkiewicz

Profesor Uniwersytetu im. Adama Mickiewicza w Poznaniu

\section{THE PRINCIPLE OF DIRECTNESS IN THE VIEW OF THE DRAFT AMENDMENTS TO THE CODE OF CRIMINAL PROCEDURE}

\section{Summary}

This paper, in memory of professor Tadeusz Nowak, is a return to his deliberations on the influence of the principle of directness on the Polish model of criminal proceedings. The dynamics in the manner of a normative approach to this directive is shown based on the analysis of the changes in the manner of incorporation of the principle of directness in the system of the criminal procedural law, and is further confirmed by a reference to the de lege ferenda proposals of the Criminal Law Codification Committee intended to restrict the scope of application of that principle. The already implemented amendments as well as these just recommended have nevertheless the same limiting goal and explicitely express postulates that have been so far discussed in an abstract way.

\footnotetext{
${ }^{35}$ Należy też zwrócić uwagę, że projektowane w nowym modelu procesu karnego przerzucenie obowiązków dowodowych na strony procesowe w sposób oczywisty rzutować będzie również na zdolność gromadzenia przez nie dowodów i prezentowania ich sądowi. Wydaje się, iż w tym względzie przewaga prokuratora jako prowadzącego postępowanie przygotowawcze będzie z racji jego pozycji organu ścigania karnego i związanych z tym kompetencji nieporównanie lepsza. Warto zastanowić się, czy sytuacja, w której sąd będzie miał do dyspozycji materiał dowodowy zgromadzony przez oskarżyciela publicznego, a wymagający przedstawienia na rozprawie $\mathrm{z}$ odstępstwem od zasady bezpośredniości i dowody zebrane przez oskarżonego prezentowane na poparcie linii obrony przeprowadzane na rozprawie bezpośrednio, będzie poprzez różny sposób zetknięcia się sądu z tym materiałem (różny stopnień pośredniości) oddziaływać na sędziowską jego ocenę. Każde bowiem ,,pośrednie” poznanie powoduje zniekształcenie informacji zawartej w dowodzie, a tym samym także przy zachowaniu zasady swobodnej oceny dowodów, wpływa na wartość danego źródła i środka dowodowego.
} 